\title{
Genetic variation in the kappa-casein gene of South African goats
}

\author{
R.C. Scheepers, E. van Marle-Köster*, C. Visser \\ Department of Animal and Wildlife Sciences, University of Pretoria, 0002, Pretoria, South Africa
}

\section{A R T I C L E I N F O}

\section{Article history:}

Received 25 June 2009

Received in revised form 9 March 2010

Accepted 9 March 2010

Available online $\mathrm{xxx}$

\section{Keywords:}

Genetic polymorphism

к-casein

Goat milk

South African goats

\begin{abstract}
A B S T R A C T
$\mathrm{\kappa}$-casein (kappa-casein) is of special interest as a milk protein polymorphism due to its known relationship with milk quality and composition. A number of allelic variants have been identified in goats. In this study, genetic variants of the $\kappa$-casein gene were evaluated in the South African Boer goat, Saanen and local unimproved goat types, using RFLP and DNA sequencing. The RFLP analysis revealed that the $A / B$ allele group recorded the highest occurrence in all the goats studied. DNA sequencing confirmed the $B$ allele (GenBank Acc. No. AF485340) to be the most common in all goat types, with allelic frequencies ranging from 0.593 in SA Boer goats to 1.0 in the Saanen. The $B^{\prime}$ allele (AY166706) was present only in the SA Boer goat and local unimproved goat types with frequencies of 0.370 and 0.143 , respectively. The $H$ allele (AF521022) was present at low frequencies in both the local unimproved goat types (0.143) and the SA Boer goat (0.037), but absent in the Saanen goats. AMOVA results indicated that most of the total variations occurred within populations (83.88\%) with only $16.12 \%$ of the variation between populations. This study found limited genetic variation for $\kappa$-casein to exist in the South African goat population.
\end{abstract}

(c) 2010 Elsevier B.V. All rights reserved.

\section{Introduction}

In South Africa, the meat goat breeds consist of the locally bred South African Boer (SA Boer) goat, and a number of local unimproved goat types that are primarily used for meat production. For commercial goat milk production the Saanen breed is used and serves a niche market for the manufacturing of cheese and other luxury dairy products. Goats are relatively cost-effective to maintain with regards to nutrition and management, compared to cattle and sheep. Due to their adaptability to harsh conditions, such as extreme temperatures and low-quality feed, goats are often used as a source of animal protein in the rural poor communities of South Africa (Donkin and Boyazoglu, 2000). In the rural smallholder systems and communal farming the local unimproved goat types and SA Boer goat are often milked for household consumption, but very little is known regarding their milk production potential or the milk com-

\footnotetext{
* Corresponding author. Tel.: +27 12 4203612; fax: +27 124203290.

E-mail address: evm.koster@up.ac.za (E. van Marle-Köster).
}

position. The potential of goats to contribute to improve the livelihoods of the resource-poor farms has been recognized in Kenya as early as the 1980s (Ahuya et al., 2005).

It has been highlighted that goat milk protein polymorphisms play an essential role in the quantity, composition and technological properties of milk (Jann et al., 2004). Certain alleles may also be linked to a bovine milk protein allergy and it is suggested that goat milk may be an alternative source in this instance (Kusza et al., 2007). Caseins comprise approximately $80 \%$ of the total protein content in milk. Although $\mathrm{k}$-casein (kappa-casein) is the least abundant of the three main groups of caseins present in ruminant milk, it has merit to screen goat breeds for the $\kappa$-casein locus for inclusion in future selection programs due to the associations between specific casein variants and superior milk composition and processing properties (Ng-Kwai-Hang and Grosclaude, 1992; Caroli et al., 2001).

This study was the first attempt to investigate genetic variation in $\mathrm{\kappa}$-casein genotypes in local unimproved goat types, SA Boer goat and Saanen in South Africa, using RFLP markers and DNA sequencing. 
Table 1

Expected restriction endonuclease fragment results per allele in goats.

\begin{tabular}{llll}
\hline Allelic variant & HaeIII & BseNI & Alw44I \\
\hline$A / B$ & $230 ; 415$ & $51 ; 235 ; 359$ & 645 \\
$C / D / G$ & $230 ; 415$ & $235 ; 410$ & $79 ; 566$ \\
$E$ & $50 ; 230 ; 365$ & $51 ; 235 ; 359$ & 645 \\
$F$ & $230 ; 415$ & $51 ; 235 ; 359$ & $79 ; 566$ \\
\hline
\end{tabular}

\section{Materials and methods}

Blood samples were collected from 5 goat populations representing 3 different geographical areas in South Africa. Two indigenous populations $(n=21)$, two SA Boer goat populations $(n=27)$, and one Saanen goat herd $(n=10)$ were sampled. Two DNA samples of known genotypes received from the Department of Veterinary Science and Food Technology at the University of Milan (Italy), were included as control samples.

DNA was extracted from whole blood using a GFX ${ }^{\circledR}$ Genomic Blood DNA Purification Kit following the standard protocol (Amersham Biosciences UK Ltd., England). A 645 bp fragment containing exon 4 of the $\mathrm{\kappa}$-casein gene was amplified using the following primers, according to the protocol of Yahyaoui et al. (2003):

\section{I3F: 5'-TCC CAA TGT TGT ACT TTC TTA ACA TC-3'}

Kb2: 5'-GCG TTG TCC TCT TTG ATG TCT CCT TAG-3

The PCR reaction was performed in a $50 \mu$ l final volume, containing 1.25 U GoTaq ${ }^{\circledR}$ Flexi DNA polymerase (Promega, Madison, WI, USA), $10 \mu \mathrm{l}$ PCR buffer, $6 \mu \mathrm{l} \mathrm{MgCl}_{2}, 10 \mathrm{mM}$ dNTP's, $10 \mathrm{pmol}$ of each primer, and $100 \mathrm{ng}$ of goat genomic DNA. The thermal cycling program was: $95^{\circ} \mathrm{C}$ for $5 \mathrm{~min}$, 10 cycles of $97^{\circ} \mathrm{C}$ for $15 \mathrm{~s}, 63^{\circ} \mathrm{C}$ for $1 \mathrm{~min}$ and $72^{\circ} \mathrm{C}$ for $1 \mathrm{~min} 30 \mathrm{~s}$, followed by 25 cycles of $95^{\circ} \mathrm{C}$ for $30 \mathrm{~s}, 63^{\circ} \mathrm{C}$ for $1 \mathrm{~min}$ and $72^{\circ} \mathrm{C}$ for $1 \mathrm{~min} 30 \mathrm{~s}$, final extension at $72{ }^{\circ} \mathrm{C}$ for 5 min and subsequent cooling to $4^{\circ} \mathrm{C}$ in a GeneAmp ${ }^{\circledR}$ PCR System 9700 (Applied Biosystems, Chesire, UK).

\subsection{RFLP analysis}

A total of 58 blood samples (10 Saanen, 21 local unimproved goat types, 27 SA Boer) and 2 DNA control samples were genotyped using the PCR-RFLP protocol (Yahyaoui et al., 2003). In the case of point mutations, differences between individuals could be detected using restriction enzymes, which cut DNA only at a specific DNA sequence, after which different alleles could be distinguished on an electrophoresis gel by bands of different lengths (Ng-Kwai-Hang and Grosclaude, 1992). The known nucleotide sequences of all the $\kappa$-casein variants were downloaded from GenBank (http://www.ncbi.nlm.nih.gov/). Although a total of 15 polymorphic sites have been identified in domestic goats, the protocol of Yahyaoui et al. (2003) only results in partial characterization of the $\kappa$ casein gene into four groups $(A / B, E, F \& C / D / G)$, as shown in Table 1 . All the known alleles' sequences were entered into the CLC Combined Workbench v3 software program (www.clcbio.com) and scanned to identify any enzymes other than those used by Yahyaoui et al. (2003), which may have recognition sites within these variants. However, none were found.

The resultant DNA restriction fragments were separated by electrophoresis in a $2 \%$ agarose gel stained with ethidium bromide (Sambrook and Russell, 2001). The fragments were compared to a size standard (50 bp DNA Step Ladder, Promega, Madison, WI, USA) and photographed.

\subsection{DNA sequencing}

All blood samples were subjected to DNA sequencing to confirm the RFLP results, and the PCR products were purified using the Wizard ${ }^{\circledR}$ SV Gel and PCR Clean-Up System (Promega, Madison, WI, USA). The sequencing reaction was performed in a $10 \mu \mathrm{l}$ final volume, containing $2 \mu$ l Therminator mix (2.5×), $1 \mu$ l sequencing buffer $(5 \times)$, $3.2 \mathrm{pmol}$ primer, and $64.5 \mu \mathrm{g}$ PCR product (BigDye ${ }^{\circledR}$ Terminator v3.1 Kit, Applied Biosystems ${ }^{\circledR}$, Chesire, UK). The thermal cycling conditions were $94^{\circ} \mathrm{C}$ for $1 \mathrm{~min}, 25$ cycles of $94^{\circ} \mathrm{C}$ for $10 \mathrm{~s}, 50^{\circ} \mathrm{C}$ for $5 \mathrm{~s}$ and $60^{\circ} \mathrm{C}$ for $4 \mathrm{~min}$, with subsequent cooling to $4^{\circ} \mathrm{C}$, using a GeneAmp PCR System 9700 (Applied Biosystems, Chesire, UK). Samples were then purified by ethanol precipitation and frozen at $-20^{\circ} \mathrm{C}$, until the sequencing run on an ABI PRISM ${ }^{\circledR} 3100$ Genetic Analyzer (Applied Biosystems, Chesire, UK).

The ClustalW 1.4 Multiple Alignment application (Thompson et al., 1994) of BioEdit Sequence Alignment Editor v.7.0.0 (Hall, 1999) was used to align sample contigs (sequences) with known allele sequences. Altogether, 15 polymorphic sites had been previously identified in this region. It was then decided to exclude two of the known $\kappa$-casein sequences from this analysis. The sequences of the $B 1$ and $B 2$ alleles (GenBank acc. numbers AF485340 and AF434988) and the D1 and D2 alleles (GenBank acc. numbers AY027868 and AY090465) were found to be identical, except that in each case one was longer. Thus, only the longer $B 1$ and $D 2$ alleles were included, based on length.

Allele and genotype frequencies of samples were determined by direct counting. Arlequin was used to perform an AMOVA for the estimation of variation within and between populations (Excoffier et al., 2005).

\section{Results}

The results of the RFLP analyses are set out in Table 2. Except for 4 of the blood samples, all other samples, including the controls ( $A A$ and $B B$ ), corresponded to the $A / B$ allele group. In 4 samples ( $3 \mathrm{SA}$ Boer and 1 local unimproved goat type), an unusual result was found where digestion with BseNI resulted in a 645 bp undigested fragment, which does not correspond to any of the expected alleles. Several repetitions were performed to eliminate the possibility of human error, but this RFLP result remained. This indicates the rather low discriminatory power of the RFLP method.

Three of the 15 known $\kappa$-casein alleles described by Prinzenberg et al. (2005), namely $B, B^{\prime}$ and $H$ were identified in the 58 blood samples subjected to DNA sequencing

Table 2

Summary of results obtained by RFLP digestion and DNA sequencing of blood samples in goats.

\begin{tabular}{|c|c|c|c|c|c|c|c|c|}
\hline \multirow[t]{2}{*}{ No. of samples } & \multirow[t]{2}{*}{ RFLP result } & \multicolumn{7}{|c|}{ Sequencing result } \\
\hline & & $\overline{A A}$ & $B B$ & $B^{\prime} B^{\prime}$ & $\mathrm{HH}$ & $B B^{\prime}$ & $B H$ & $B^{\prime} H^{\prime}$ \\
\hline \multicolumn{9}{|l|}{ SA Boer goats } \\
\hline 24 samples & $A / B$ allele group & & 9 & 5 & & 8 & & 2 \\
\hline 3 samples & Unusual result & & 3 & & & & & \\
\hline \multicolumn{9}{|c|}{ Local unimproved goat types } \\
\hline 20 samples & $A / B$ allele group & & 13 & 2 & 1 & 2 & 2 & \\
\hline 1 sample & Unusual result & & & & 1 & & & \\
\hline \multicolumn{9}{|l|}{ Saanen goats } \\
\hline 10 samples & $A / B$ allele group & & 10 & & & & & \\
\hline \multicolumn{9}{|l|}{ Control DNA } \\
\hline 2 samples & $A / B$ allele group & 1 & 1 & & & & & \\
\hline
\end{tabular}

Heterozygous at two nucleotide positions. 
Table 3

Frequencies of kappa-casein alleles in three goat genotypes (GenBank accession numbers in brackets).

\begin{tabular}{llll}
\hline Allele & $n$ & B(AF485340) & $B^{\prime}($ AY166706) \\
\hline SA Boer goat & 27 & 0.593 & 0.370 \\
Local unimproved goat types & 21 & 0.714 & 0.143 \\
Saanen & 10 & 1 & 0.037 \\
\hline
\end{tabular}

Table 4

Analysis of molecular variance (AMOVA) results for 7 goat populations using the Arlequin program.

\begin{tabular}{lrllr}
\hline Source & df & SS & Esimated variance & $\%$ \\
\hline Among populations & 2 & 0.918 & 0.1974 & 16.12 \\
Within populations & 55 & 5.651 & 0.10274 & 83.88 \\
Total & 57 & 6.569 & 0.10858 & 0.16117 \\
\hline
\end{tabular}

(Table 2). The $B$ allele was the most common allele, with frequencies ranging from 0.593 in the SA Boer goat to 1.0 in the Saanen. The $B^{\prime}$ allele was present only in the SA Boer goats and local unimproved goat types, with frequencies of 0.370 in and 0.143 , respectively. The $H$ allele was also present at low frequencies in the local unimproved goat types (0.143) and SA Boer goats (0.037) as shown in Table 3. The AMOVA results set out in Table 4 , indicated that $83.88 \%$ of the total variation occur within populations, with the remainder of the variation occurring among populations $\left(F_{\mathrm{ST}}=0.122, p \leq 0.05\right)$.

\section{Discussion}

Restriction endonucleases have been important tools in DNA studies. RFLP technology has been used extensively in similar studies (Yahyaoui et al., 2001) and has several advantages, including being a relatively inexpensive method. However, RFLP methodology is often used in conjunction with another method to ensure maximum discrimination of alleles, e.g. SSCP (Prinzenberg et al., 2005). DNA sequencing is, however, becoming the method of choice due to higher specificity and accuracy (Martin et al., 2006). Especially if funding is limited, researchers may use RFLP analysis for screening of the total sample set for polymorphism, after which, samples exhibiting different RFLP patterns are subjected to DNA sequencing analysis (Caroli et al., 2006).

Several studies have indicated a high level of polymorphism in the $\kappa$-casein gene in goats (Yahyaoui et al., 2001; Jann et al., 2004). Due to differences in the interpretation between type and variant and a number of almost simultaneous publications of $\kappa$-casein variants, it was shown by Prinzenberg et al. (2005) and Reale et al. (2005) that inconsistencies in the nomenclature exist, caused by the assignation of the same letter to different variants. To avoid confusion, this study only used the nomenclature as assigned by Prinzenberg et al. (2005). Currently, two $\kappa$-casein types can be identified by iso-electric focusing (IEF), namely AIEF and BIEF, and all $\kappa$-casein variants or alleles $(A$ to $M$ ) can be categorized into these two groups (Prinzenberg et al., 2005; Caroli et al., 2006).

Only 3 of the 15 previously identified variants (Prinzenberg et al., 2005) were detected in this study. The $B, B^{\prime}$, and $H$ alleles all belong to the AIEF variant, which is the less favourable $\kappa$-casein variant in terms of milk composi- tion and technological properties (Haenlein, 2002; Chiatti et al., 2007).

The most variation was recorded in the local unimproved goat types, with 3 alleles $\left(B, B^{\prime}, H\right)$ present in varying frequencies, while the Saanen goat was homozygous for the $B$ allele. In a study by Yahyaoui et al. (2003) on 10 goat breeds using the same PCR-RFLP methodology, the $B$ allele also being found to be the only variant present in all breeds analyzed, with frequencies ranging from 0.4 to 0.7 - similar to the present study. Prinzenberg et al. (2005) investigated the variation of $\kappa$-casein in 7 breeds, using different methods and reported a high frequency of the $B / B^{\prime}$ alleles (0.260-0.660) and the $A$ allele (0.151-0.414) - with the other alleles all having much lower frequencies. The $A$ and $B$ alleles were present in all 7 breeds analyzed by Prinzenberg et al. (2005).

Two of the local unimproved goat blood samples were heterozygous $B B^{\prime}$, while two were heterozygous $B H$. In the SA Boer goat, 8 of the 27 samples showed $B B^{\prime}$ heterozygosity, and in two samples heterozygosity was observed at two SNP positions. Nucleotide position 170 is heterozygous for nucleotides $T / C$ and nucleotide position 274 is heterozygous for $A / G$. Thus, these two samples are heterozygous $T C-A G$ by haplotypes $T-A$ and $C-G$.

Results indicated only a small variation in the $\kappa$-casein gene in the SA Boer goat and the local unimproved goat. The AMOVA indicated that only $16.12 \%$ of the variation can be attributed to differences between the populations, while $83.88 \%$ of the variation was contributed from within the populations studied. It was interesting to note that the Saanen population in this study exhibited no variation for the к-casein gene.

Future studies should concentrate on the association between goat genotype and milk composition characteristics, in order for it to make a useful contribution in the upliftment of the rural communities. In addition, the fact that caseins are encoded by a tight $250 \mathrm{~kb}$ cluster of 4 genes, in the order CSN1S1, CSN2, CSN1S2 and CSN3, indicates that future research should concentrate on casein haplotypes and not on one casein gene alone (Jann et al., 2004; Bozkaya et al., 2008).

\section{Conclusion}

Local unimproved goat types in South Africa have a role to play in household food security with regards to 
both meat and milk. The results of this study indicate that genetic variation for $\kappa$-casein exist, and further studies with larger sample sizes and inclusion of other milk genes can now be considered.

\section{Acknowledgements}

The author wishes to acknowledge the assistance and expertise of Prof. E.F. Donkin, Dr. W. Markotter, and Ms. R. Zipfel. This work was supported by the Department of Animal and Wildlife Sciences, University of Pretoria.

\section{References}

Ahuya, C.O., Okeyo, A.M., Mwangi-Njuru, Peacock, C., 2005. Developmental challenges and opportunities in the goat industry: the Kenyan experience. Small Rumin. Res. 60, 197-206.

Bozkaya, F., Mundan, D., Karabulut, O., Yerturk, M., Gurler, S., Aral, F., 2008. An investigation on the distribution of $\mathrm{O}$ and $\mathrm{D}$ alleles of the CSN1S2 gene in goat populations raised in southeastern region of Turkey. Small Rumin. Res. 78, 193-196.

Caroli, A., Jann, O., Budelli, E., Bolla, P., Jager, S., Erhardt, G., 2001. Genetic polymorphism of goat $\kappa$-casein (CSN3) in different breeds and characterization at DNA level. Anim. Gen. 32, 226-230.

Caroli, A., Chiatti, F., Chessa, S., Rignanese, D., Bolla, P., Pagnacco, G., 2006. Focusing on the goat casein complex. J. Dairy Sci. 89, 3178-3191.

Chiatti, F., Chessa, S., Bolla, P., Cigalino, G., Caroli, A., Pagnacco, G., 2007. Effect of the $\kappa$-casein polymorphism on milk composition in the Orobica goat. J. Dairy Sci. 90, 1962-1966.

Donkin, E.F., Boyazoglu, P.A., 2000. Milk production from goats for household and small-scale farmers in South Africa. In: Proceedings of the 7th International Conference on Goats (1), pp. 324-328.

Excoffier, Laval, L.G., Schneider, S., 2005. Arlequin ver. 3.0: an integrated software package for population genetics data analysis. Evol. Bio. Online 1, 47-50.
Haenlein, G.F.W., 2002. Lipids and proteins in milk, particularly goat milk. <www.ag.udel.edu/extension/information/goatmgt/gm-08.htm>.

Hall, T.A., 1999. BioEdit: A user-friendly biological sequence alignment editor and analysis program for Windows 95/98/NT. Nucl. Acids. Symp. Ser. 41, 95-98.

Jann, O.C., Prinzenberg, E.M., Luikart, G., Caroli, A., Erhardt, G., 2004. High polymorphism in the kappa-casein (CSN3) gene from wild and domestic caprine species revealed by DNA sequencing. J. Dairy Res. 71, $188-195$.

Kusza, S., Veress, G., Kukovics, S., Javor, A., Sanchez, A., Angiolillo, A., Bosze, Z., 2007. Genetic polymorphism of $\alpha s 1$ - and $\alpha$ s2-caseins in Hungarian milking goats. Small Rumin. Res. 68, 329-332.

Martin, E.T., Koelle, D.M., Byrd, B., Huang, M.-L., Vieira, J., Corey, L., Wald, A., 2006. Sequence-based methods for identifying epidemiologically linked herpes simplex virus Type 2 strains. J. Clin. Microbiol., 2541-2546.

Ng-Kwai-Hang, K.F., Grosclaude, F., 1992. Genetic polymorphism of milk proteins. In: Fox, P.F. (Ed.), Advanced Dairy Chemistry, vol. 1. Elsevier Science Publishers Ltd., London, pp. 405-455.

Prinzenberg, E.-M., Gutsher, K., Chessa, S., Caroli, A., Erhardt, G., 2005. Caprine kappa-casein (CSN3) polymorphism: new developments in molecular knowledge. J. Dairy Sci. 88, 1490-1498.

Reale, S., Yahyaoui, M.H., Folch, J.M., Sanchez, A., Pilla, F., Angiolillo, A., 2005. Short communication: genetic polymorphism of the kappacasein (CSN3) gene in goats reared in Southern Italy. Ital. J. Anim. Sci. 4, 97-101.

Sambrook, J., Russell, D.W., 2001. Molecular Cloning. A Laboratory Manual third, vol. 1., 3rd ed. Cold Spring Harbor Laboratory Press, NY (5.4).

Thompson, J.D., Higgins, D.G., Gibson, T.J., 1994. CLUSTAL W: improving the sensitivity of progressive multiple sequence alignment through sequence weighting, position specific gap penalties and weight matrix choice. Nucleic Acids Res. 22 (22), 4673-4680.

Yahyaoui, M.H., Coll, A., Sanchez, A., Folch, J.M., 2001. Genetic polymorphism of the caprine kappa casein gene. J. Dairy Res. 68, 209-216.

Yahyaoui, M.H., Angiolillo, A., Pilla, F., Sanchez, A., Folch, J.M., 2003. Characterization and genotyping of the caprine kappa-casein variants. J. Dairy Sci. 86, 2715-2720. 